\title{
Device for craniocervical isolation in rabbits ${ }^{1}$
}

\author{
Dispositivo para isolamento crânio-cervical em coelhos
}

\author{
Cláudio Santana Ivo ${ }^{\text {, }}$ Marcelo Braga Ivo ${ }^{\text {II }}$, Paulo Guilherme de Oliveira Salles ${ }^{\text {III }}$, Ricardo Costa Val do Rosário ${ }^{\text {IV }}$, Tarcizo Afonso \\ Nunes ${ }^{\mathrm{V}}$ \\ ${ }^{\text {I }}$ Fellow Master degree in Surgery, School of Medicine, UFMG, Minas Gerais, Brazil. \\ II Graduate Student, Medical School, UFMG, Minas Gerais, Brazil. \\ ${ }^{\text {III }}$ Fellow PhD degree, Surgery, School of Medicine and Assistant Professor, Pathology, Medicine School, UFMG, Minas Gerais, Brazil. \\ Iv $\mathrm{PhD}$, Assistant Professor, Bioethics and Surgery School of Medicine Uni-BH, Brazil. \\ ${ }^{v}$ Associate Professor, Department of Surgery, School of Medicine, UFMG, Minas Gerais, Brazil.
}

\begin{abstract}
Purpose: To evaluate the craniocervical isolation collar, for use in rabbits, with regard to the following aspects: effectiveness of the craniocervical attachment for up to 120 hours; ease of handling; freedom of the animal to move about and ingest food; and the physical integrity of the animal during and after use of the device. Methods: Starting from an Elizabethan collar, a craniocervical collar was prepared for use in rabbits with the following modifications: a wide cut in the device in the shape of a half-moon, coinciding with the animal's mouth; inner division of the device into two compartments to individually isolate and immobilize the ears; multiple perforations in the upper compartment for better ventilation; adaptation of the cervical-thoracic band to attach the collar to the cervical region, keeping the fasteners on the animal's back. The device was used on 18 male New Zealand rabbits for up to 120 consecutive hours. Results: The device was effective in the craniocervical isolation and separation of ears in rabbits without interfering with the animals' respiration, ability to swallow food, or causing physical trauma, while allowing the animals to move about freely and rest comfortably. Attaching and removing the device was easy and quick and it remained in place for up to 120 hours without the need to reposition it. Conclusion: The modified craniocervical isolation collar made it possible to conduct the experiment with isolation of the rabbits' ears, ease of handling, and without causing limitations in relation to the animals' ability to eat and move about freely.
\end{abstract}

Key words: Instrumentation. Animal Experimentation. Models, Animal. Rabbits.

\section{RESUMO}

Objetivo: Avaliar um colar de isolamento crânio-cervical, para uso em coelhos, quanto aos seguintes aspectos: eficácia da fixação crânio-cervical em até 120 h; facilidade de manuseio; liberdade do animal para deambular e ingerir alimentos; integridade física do animal durante e depois do uso do dispositivo. Métodos: A partir do colar elizabetano confeccionou-se um colar de isolamento crânio-cervical para uso em coelhos, com as seguintes modificações: amplo corte no aparelho, em forma de meia lua, coincidindo com a boca do animal; divisão interna do dispositivo em dois compartimentos, para isolar e imobilizar as orelhas, individualmente; perfurações múltiplas no compartimento superior para melhor ventilação; adaptação de correia cérvico-torácica, para fixar o colar na região cervical, mantendo-se as presilhas de fechamento no dorso do animal. O dispositivo foi utilizado em 18 coelhos machos da raça Nova Zelândia, por período de até 120 horas consecutivas. Resultados: O aparelho foi eficaz no isolamento crânio-cervical e das orelhas de coelhos, não interferiu nas funções respiratórias do animal, na deglutição de alimentos e não causou trauma físico, permitindo a livre deambulação e conforto no repouso. Foi de fácil e rápido manuseio na colocação e retirada, permanecendo no local sem necessidade de reposicionamento por até 120 horas. Conclusão: O colar de isolamento crânio-cervical modificado possibilitou a realização do experimento com isolamento das orelhas dos coelhos, com facilidade no manuseio, sem causar limitações ao animal em relação à ingestão de alimentos e deambulação. Descritores: Instrumentação. Experimentação Animal. Modelos Animais. Coelhos.

${ }^{1}$ Research performed at the Postgraduate Program in Applied Sciences of Surgery and Ophthalmology, Federal University of Minas Gerais (UFMG), Brazil.

\section{Introduction}

Among the various species of animals, rabbits, rats, and dogs are the most frequently used for experimental research and educational purposes ${ }^{1,2,3}$.
These animals have unique characteristics that determine them for specific types of experiments. The rabbit, for instance, can easily contort itself and move its ears excessively, managing to 
nip, lick, and use its paws to reach almost the entire surface of its body. This mobility limits experimental handling, especially of the ears, through the difficulty in isolating these regions. It is, therefore, necessary to find measures that are capable of impeding the animals from having access, with their paws or mouth, to parts of the body that are being experimentally handled. The purpose of these measures is to prevent removal of any dressing and ingesting any object or substance that could compromise the health of the animal or interfere with the results of the experiment. There are few references in the literature to such devices. It is up to the researcher to devise ways of isolating specific regions of the animal so that the experiment can be concretized.

In consideration of experimental research for a Master's thesis, approved by the Ethics Committee on Animal Experimentation (CETEA) of the Federal University of Minas Gerais (UFMG), on March 27, 2007, protocol number 184/2006, a device was conceived starting with a collar available on the veterinary market for use in dogs and cats, known as an Elizabethan collar $^{\circledR 4,5}$ (Figure 1).

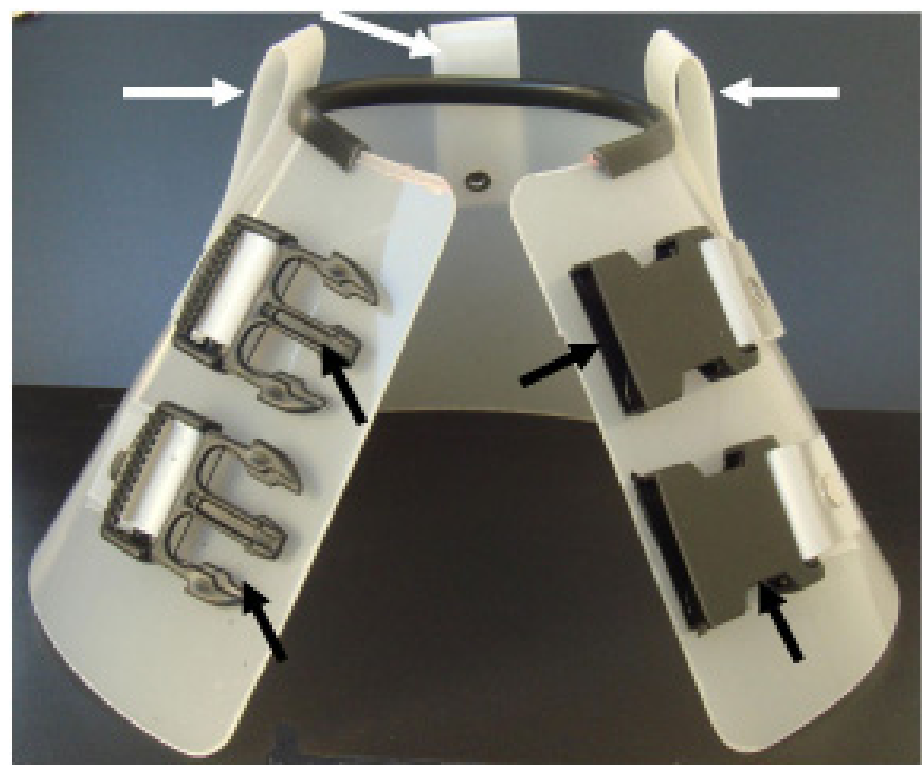

FIGURE 1 - Photograph of an open Elizabethan collar, supported on a flat surface on its anterior side (opening for the animal's head), showing the fasteners in an open position (black arrows) and straps of the attachment band positioned next to the neck opening of the device (white arrows)

This was initially used in the pilot group. However, it proved to be inadequate for its intended purpose by not satisfying the following needs: attachment of the device in a single position, ventilation and individual isolation of the ears, and ability to eat and move about freely. Once these needs had been identified for conducting the experiment, modifications were made to the original Elizabethan collar, which resulted in another device quite different from the first one.

The purpose of this study was to evaluate the modified craniocervical isolation collar, while conducting experiments on rabbit ears, with regard to the following aspects: craniocervical attachment; ease of handling the collar; effectiveness of the attachment; and freedom of the animal to move about and eat freely, all without interfering with the physical integrity of the animal.

\section{Methods}

To satisfy the needs identified in the pilot test, a craniocervical isolation collar was developed by making several modifications and adaptations to the Elizabethan collar as described below:

* Cut in the wide shape of a half moon, placed opposite the fasteners, and coinciding with the animal's mouth to permit ingestion of food without restrictions. (Figure 2);

* Division of the inner compartment of the device into two compartments: a small one in the upper part to accommodate and isolate the ears and a larger one in the lower part, containing the rest of the animal's head. This division was made by fashioning a second mobile piece, made with the same type of plastic used in the device, then positioning it after the main part of the collar has been attached to the animal's neck. This piece is held in place by braces with ties threaded in the brace holes, which coincide with the holes in the body of the device, made especially for this purpose (Figure 3).

* Multiple perforations in the compartment divider and the upper part of the compartment for the ears to permit better ventilation (Figure 4).

* Adaptation of the cervical-thoracic band (made of cotton cloth) for positioning and attaching the collar to the cervical region, thus preventing it from turning around on the animal's neck and undoing the ear attachment and altering the correct position of the half moon cut (Figure 5). The attachment band is introduced through the collar's lower loop strap, with its two ends being of equal length that run through the animal's back paws. From there, they encircle the thorax, separately, cross over the animal's shoulders, pass through the collar's upper loop straps on the left and right sides, and are then attached to the brace or joined with Velcro (Figure 6).

* Transversal division of the upper compartment in two parts by means of a longitudinal brace with ties between the dividing piece and the main body of the collar for accommodating and isolating the ears (Figure 7);

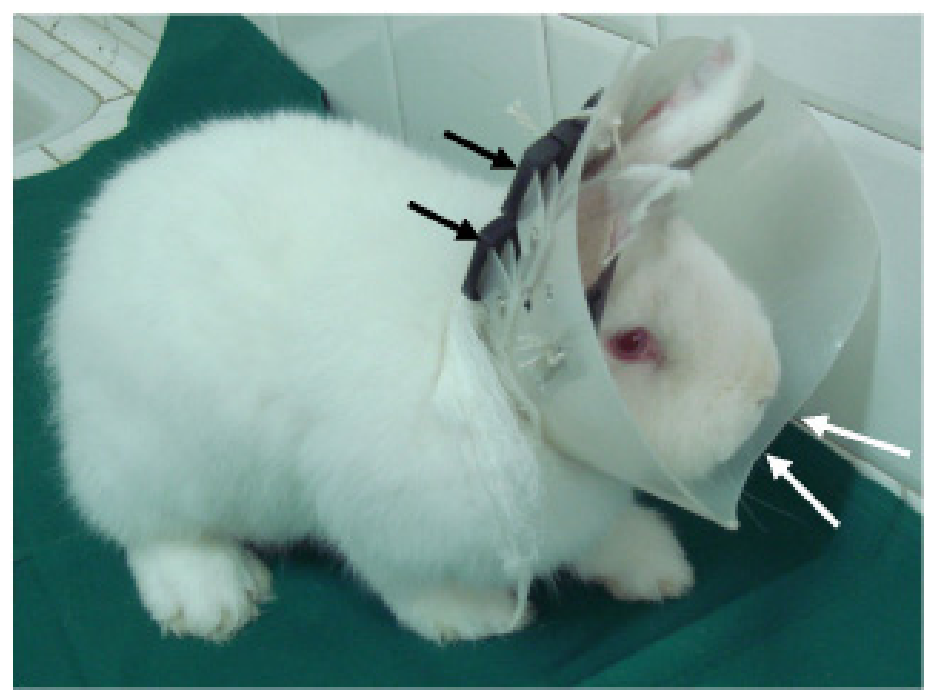

FIGURE 2 - Photograph of a rabbit wearing the collar, showing the position of the fasteners on the back of the neck (black arrows) and the half-moon CUT coinciding with the mouth of the animal (white arrows), placed opposite the fasteners 

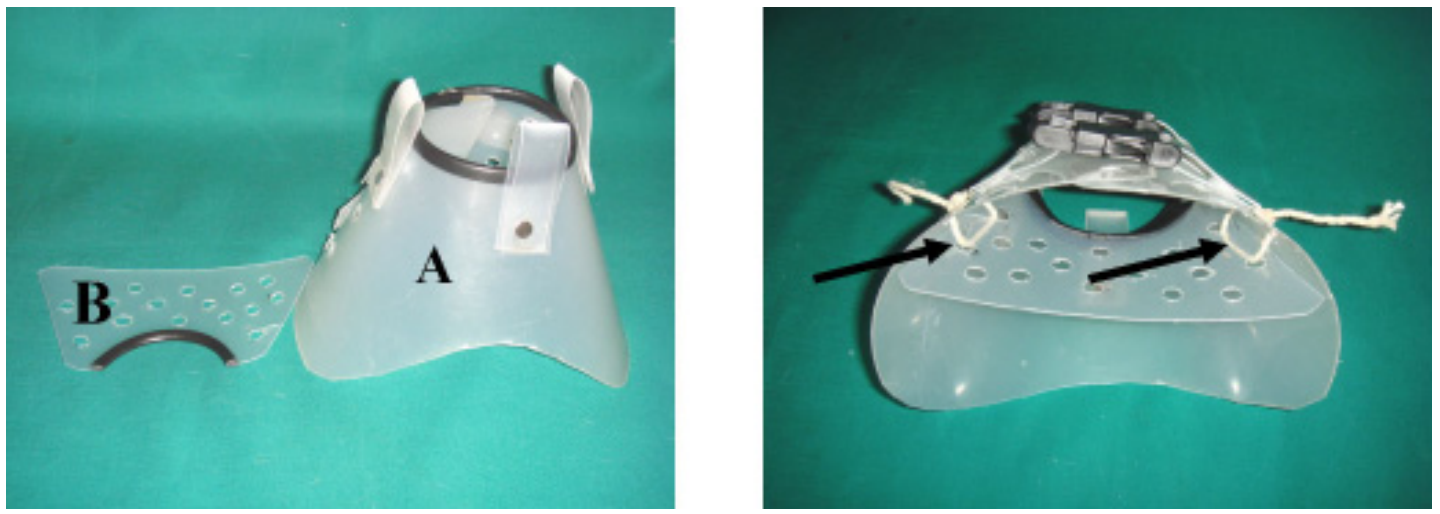

FIGURE 3 - A. Photograph of cervical isolation collar for rabbits, showing the main body of the device (A) and the divider for isolating the ears (B), separated and supported on a flat surface. B. Detail of the divider attachment on the main body of the device with threaded braces (black arrows).

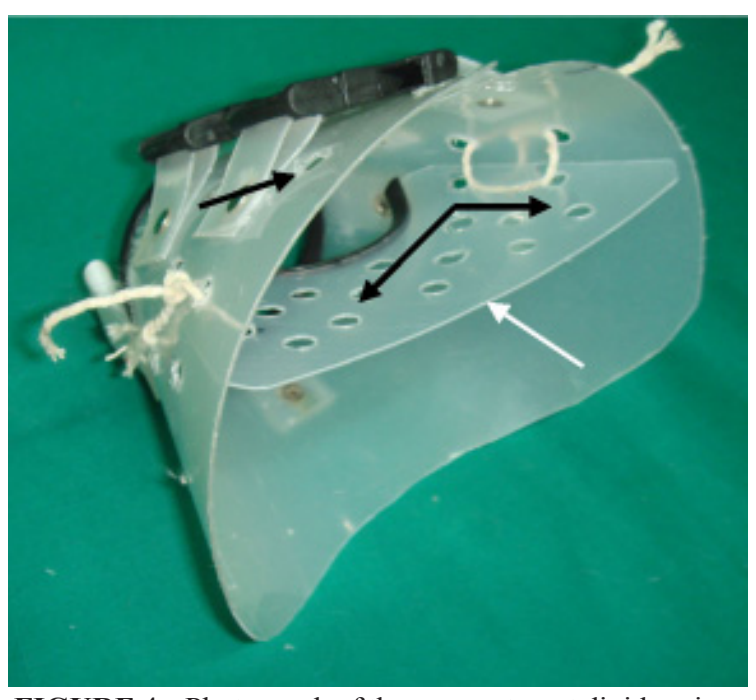

FIGURE 4 - Photograph of the compartment divider piece in position (white arrow). Detail of the holes in the divider and the upper compartment to permit better ventilation of the ears (black arrows)

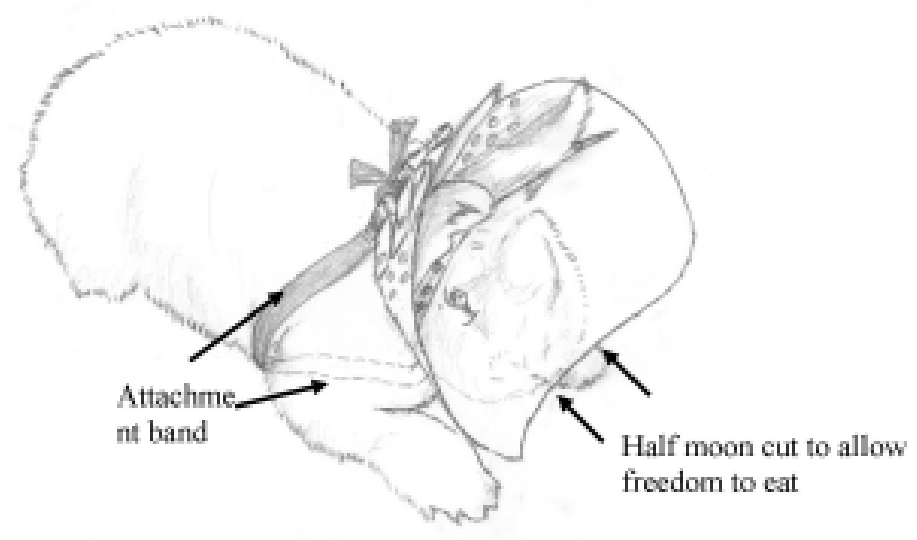

FIGURE 5 - Detail of the course of the attachment band on the side of the thorax from one side to the other (band seen from the right side) and on the ventral area through the back paws of the animal (traced). The half moon cut allows the animal to feed freely

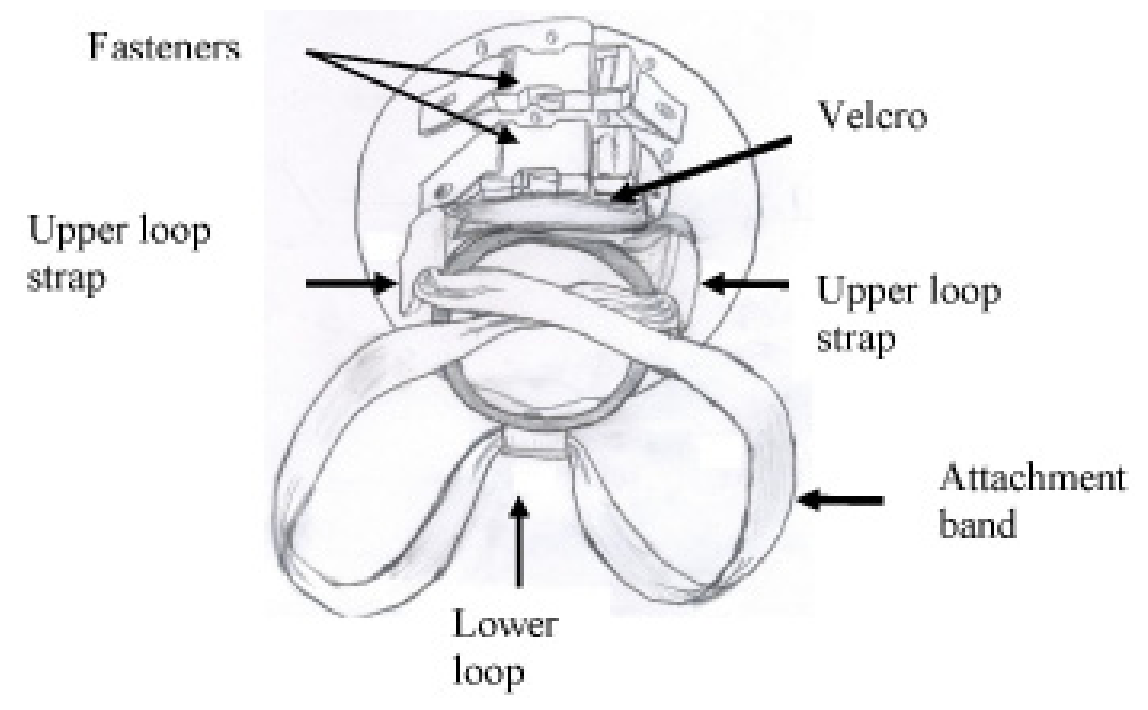

FIGURE 6 - Drawing of the posterior view of the cervical isolation collar for rabbits, closed with the back fasteners (see indication), showing how the attachment band passes through the upper and lower loop straps, as indicated, and how the free ends are joined together at the back of the neck with Velcro 


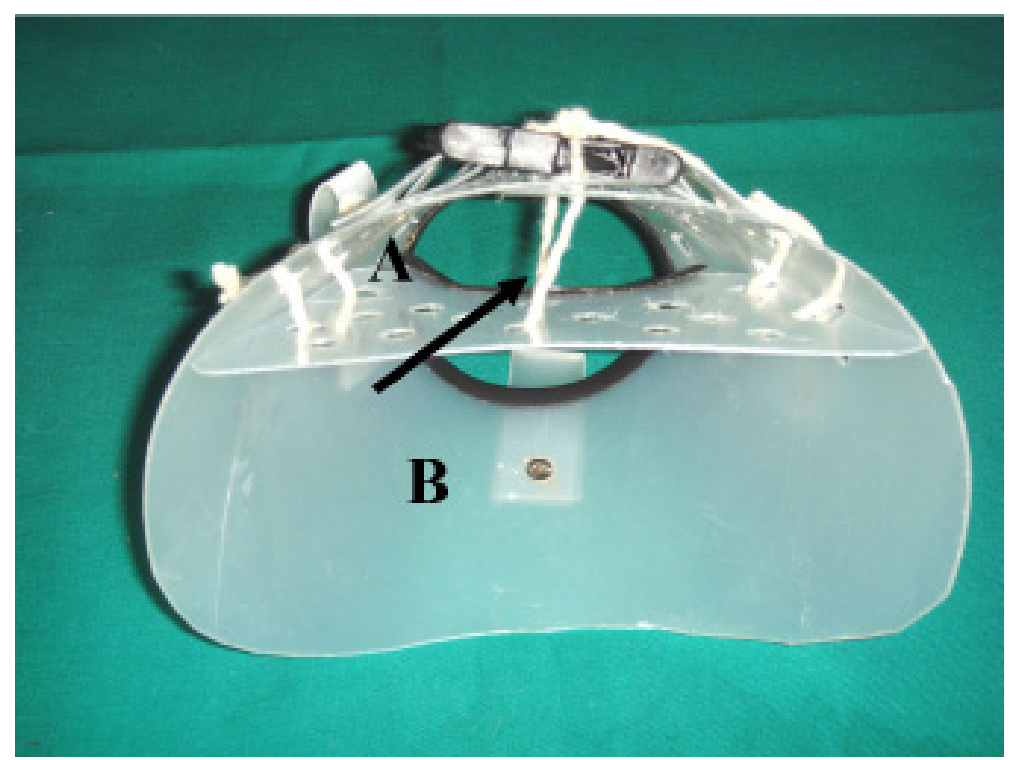

FIGURE 7 - Photograph of the front of the collar showing how it is dividing into two compartments, upper (A) and lower (B). Detail of the upper compartment for individual isolation of the ears, left and right, with a simple transversal brace with ties (black arrows)

The craniocervical isolation collar was used in an experiment during which it was necessary to isolate the two ears of 18 male New Zealand rabbits, distributed in three groups (A, B, and $C$ ) of six animals. The collar was kept on for different lengths of time for each group: group A, 24 hours, group B, 72 hours, and group C, 120 hours.

\section{Results}

The device was effective in craniocervical isolation in rabbits. The longitudinal division of the upper compartment with a brace with ties allowed for the semi-immobilization of the ears, individually.

The collar did not interfere with the animals' respiratory functions or inhibit their ability to eat freely. It also allowed them to move about at will and rest comfortably. It did not cause any physical trauma and the animals were active and calm throughout the experiment. Following the removal of the collar, the animals' behavior was observed to be normal, including movement of the ears.

The collar was easy and inexpensive to make and easy and quick to put on and take off, remaining in place without the need to reposition it throughout the experimental period (maximum of 120 hours).

\section{Discussion}

Ethical questions related to the scientific research involving the use of live animals are an important and essential step for the development of science. Appropriate and responsible handling of the animals is essential, with the researcher being obliged to be familiar with all procedures that envision the well-being and safety of the animal as well as that of the researcher him/herself ${ }^{3,6,7,8}$.
In some experiments, it is necessary to impede the animal from being able to reach the parts of its body being handled or that serve as a means of access for invasive measures, thus preventing the animal from gnawing at stitches, swallowing objects that could be harmful to its health, or even cause injury to itself.

In the research that gave rise to the preparation of the device described in this article, it was absolutely necessary to isolate and immobilize the rabbits' ears, as reported in the pilot test. The experimental results depended on the histological evaluations of the marginal dorsal veins and contiguous tissue of the ears after a sclerosing injection and extrinsic mechanical compression.

It was essential that the device, which had been especially designed for the study, remain in the initial position until its removal after being in place for 24 hours to 120 hours.

A cervical position collar would be ideal. However, the ventral position of the animal's mouth indicated that the device would have to be short enough to allow the animal to eat while, at the same time, having sufficient lateral and upper projections to completely cover the ears and prevent the animal from reaching the handled locations with its paws or mouth. This would mean developing a way of attaching the collar so that it would not turn around on the neck during use. Moreover, the individual isolation of the ears was necessary to prevent the animal from dislodging or removing any devices and dressings with a simple shake of its head.

Adequate ventilation of the ears was also necessary as they play an important role in regulating the animal's body temperature ${ }^{9,10}$.

After several attempts had been made at developing a prototype device that would enable adequate isolation of the ears, the device herein describe was developed for use in rabbits, which proved to be efficient for this purpose.

Owing to the paucity of material in the medical literature concerning this type of device, the publication of this article was deemed appropriate, keeping in mind that such a device can be 
used in any experiment with rabbits that require craniocervical isolation of the animal. The longitudinal dividing brace in the upper compartment or even the two-compartment divider itself can be dispensed with in research that does not specifically require isolation of the ears. It should be emphasized that the collar was used with success for 120 hours and periods beyond that must be evaluated in other studies.

\section{Conclusion}

The modified craniocervical isolation collar facilitated the performance of the experiment with isolation of the rabbits' ears, with ease in handling and without limiting the animals' ability to eat and move about freely, thereby satisfying the principles that guide animal experimentation.

\section{References}

1. Schnaider TB, Souza C. Aspectos éticos da experimentação animal. Rev Bras Anestesiol. 2003;53(2):278-85.

2. Magalhães M, Ortêncio Filho H. Alternativas ao uso de animais como recurso didático. Arq Ciênc Vet Zool Unipar. 2006;9(2):147-54.
3. Pimenta LG, Silva AL. Ética e experimentação animal. Acta Cir Bras. 2001;16(4):255-60.

4. Silva MR, Aleixo GAS, Sá FB, Coelho MCOC. Redução de fenda palatina secundária em um gato. Ciênc Vet Tróp. 2006;9(2/3):97-101.

5. Mota FCD, Eurides D, Freitas PMC, Beletti ME, Goulart MR, Cunha L M, Silva LAF, Fioravanti MCS. Utilização do adesivo N-butil cianoacrilato e o do fio poliglactina na rafia de córnea em coelhos (Oryctolagus cunicullus). Braz J Vet Res Anim Sci. 2003;40:334-40.

6. Petroianu A. Aspectos éticos nas pesquisas em animais. Acta Cir Bras. 1996;11(3):157-64.

7. Schanaider A, Silva PC. Uso de animais em cirurgia experimental. Acta Cir Bras. 2004;19(4):441-7.

8. Marques RG, Miranda ML, Caetano CER, Biondo-Simões ML. Rumo à regulamentação da utilização de animais no ensino e na pesquisa científica no Brasil. Acta Cir Bras. 2005;20(3):262-7.

9. Fayes MM, Alnaimy MH. Thermorregulation in rabbits. CIHEAM Options Mediterraneennes. Available from URL: http:// ressources.ciheam.org/om/pdf/c08/95605277.pdf [Access in 2008 Dez 22].

10. Machado LC, Ferreira WM. Fundamentos de conforto ambiente aplicados à cunicultura. Available from URL: http:// www.coelhoecia.com.br/Zootecnia/Fundamentos $\% 20$ de $\%$ 20 conforto $\% 20$ ambiente $\% 20$ aplicados $\% 20 a \% 20$ cunicultura.pdf [Access in 2008 Jan 5].

Conflict of interest: none

Financial source: none

\section{Correspondence:}

Cláudio Santana Ivo

Rua Tomé de Souza, 300/1301

30140-130 Belo Horizonte - MG Brazil

Phone: (55 31)3284-9810

claudiosivo@yahoo.com.br

Received: January 13, 2009

Review: March 11, 2009

Accepted: April 14, 2009

\section{How to cite this article}

Ivo CS, Ivo MB, Salles PGO, Rosário RCV, Nunes TA. Device for craniocervical isolation in rabbits. Acta Cir Bras. [serial on the Internet] 2009 July-Aug;24(4). Available from URL: http://www.scielo.br/acb 